SHS Web of Conferences 2, 00004 (2012)

DOI: $10.1051 /$ shsconf/20120200004

(C) Owned by the authors, published by EDP Sciences, 2012

\title{
Change of values in the consumer society
}

\author{
S. Austruma
}

\author{
Rezekne Higher Education Institution, Latvia
}

\begin{abstract}
A common feature of our age is orientation of young people towards transitional values. Economic partnership of consumer society has a direct impact on values of society and even if the process of change of values can be affected by formers of education politics, economists and politicians, young people still choose values, which conform with their own lifestyle. Content of educational subjects is connected with study, succession of cultural values, study of classified knowledge and skills, which is also a prerequisite of formation of personality. Societies of all ages has formed according to the specific mechanism, accumulating and integrating general, notable at that time ideas, preserving and transforming their own social experience to the next generations. Each culture declares itself from its scale of values and norms. Priority of change of post material and material values changes together with conditions of cultural, historical and social-political life. Change of paradigms is change of viewpoint of the world, therefore conditions of value choice relate not only to separate groups, but to whole cultures. Young people, similar to other members of society, are forced to construct their own identity and to form their own life insurance strategies offered by the consumer society. Consumer society forms its values and it is creator of its own significance, but young people as social agents are reproducers of values of consumer society. Research results of World Value Surveys (WVS) from six continents discovered big differences in value priorities between younger and older generations, which indicates not only inter-generation value change, but also changes in the whole society. The research "Value choice of young people in consumer society" in our country shows, that although the lifestyle of young people is pragmatic, traditional value - family is also one of the most often mentioned and important values in consumer society. But education is the one, which gives them moral and attested material support in the future. The education must not only educate the society, but also has to carry a comprehensive content that would hold culture memories and the transfer of it. In the research family as the main value in choice of values of young people stands side by side with such values as health and love, which in case of paradigm of consumer society would not be clearly definable as material or post material values.
\end{abstract}

Key words: values of young people, post-materialist values, materialist values, consumer society, mass media

Perspective of development of society and conditions of its vital development reflects in communicative relationships between society, standards of education system, economics and state politics. Fast economical development and welfare, as a priority of individual, implemented new criteria in relationships of individual, society and education. Although relationships between members of society and generations are still connected, it is still necessary to acknowledge the possibilities of self-realization of individual. A fast transfer of priorities of basic values of generations has occurred - from values of materialism to values of post materialism.

Change of paradigms is change of viewpoint of the world, therefore conditions of value choice relate not only to separate groups, but to whole cultures, including attitude towards education as value.

Consumer society forms its values and it is creator of its own significance, but young people as social agents are reproducers of values of consumer society, like a carjer, many, entertainment. The politics of education should be given a special importance in the age of economic crisis when mass thinking and wants is being formed by the web of media.

This is an Open Access article distributed under the terms of the Creative Commons Attribution License 2.0, which permits unrestricted use, distribution, and reproduction in any medium, provided the original work is properly cited. 


\section{SHS Web of Conferences}

\section{Post material values are replacing material values}

Every body of culture society forms according to certain mechanism, or scheme, firstly it is born, then it accumulates and integrates ideas, preserve and transform social experience in other cultures, thus provide their cultural historical existence.

Research made in many countries of the world concludes that human values mainly are fixed, when people reach the age of adults and further these values change relatively (Inglehart, 2005). In research of the last thirty years value change mechanism has been analyzed, using three different approaches - cohort analysis (Cohort in Latin - "enclosed area") and comparison of rich and poor countries. In post modern culture evaluation of value choice tendencies has been summarized in conclusions, that significant cultural changes are happening and that they reflect inter-generation changes, which are directly connected with increasing level of safety of existence. Indicator of consumer society is crowd thinking, which is one of psychological aspects of choice of values, strategy and ideology of young people. By diversification of society it is becoming more complicating to solve efficiently life problems of separate individuals by the help of collective resources.

Differentiating cultural ages, such concept as style has come in the awareness of people. People begin to choose such lifestyle, which symbolizes their values and demonstrates their identity. That significant cultural changes are happening and that they reflect inter-generation changes, which are directly connected with increasing level of safety of existence. In research of the value change mechanism has been analyzed, using spcific approaches - cohort analysis, which divides in:

Veteran, born before 1946 actions and value choice of so called veterans has in many ways affected by war and events of that time. Feeling of safety and comfort is important to veterans.

Baby boomers, born 1946-1964. Baby boomers are characterized as - post war "demographic explosion" generation, developers of economics and hard workers, who very often were in deficit of time for family and rest. Social affiliation and status in work are important for this generation.

Gen X, born 1965-1979. X generation has grown independently, because parents were always busy at work. This generation has obtained good education, they are more self-confident and bigger individualists, personal values as sense of responsibility and personal freedom are common in their value choice.

Gen Y, Net generation, Dot-Com generation, born 1980-1994. The generation of my comparison in my research is generation $\mathrm{Y}$, which is smart in technologies and oriented towards success. Its main value is appreciation/recognition, which is obtained through career. This generation is characterized by harmonic attitude towards both - career and family.

Digital Natives, born after 1994. However Z generation (Digital Natives) is online generation, which has grown in and lives in non-stop connection 24 hours in the 7.

Studying description of $\mathrm{Y}$ and $\mathrm{Z}$ generation, it should be concluded that in Latvia this description relates to those people, who are born around 1990 and later, which means - without experience of living in Soviet Union, grown in environment of free speech and free opinion. They are youngsters born in 90ies with attitude and perception, which substantially differs from previous generations.

The serios Australian Sociologist Ronald Inglehart performing research on values of society emphasized economical factors of industrial and post-industrial society, which affect mind and value choice of individual. According to R. Inglehart changes in dominance of values are surprising. Among 65 years old and older people (veteran generation) materialistic values dominate. Younger generations, which has grown in environment, where survival goals mostly were achieved, tends more to choose "post material" values - self -expression, individual freedom, social equality, quality of life.

The idea behind the theory of value changes of material to post material values is that values of post materialists are born due to constant trend, where people emphasize autonomy of foundation of their existence, self-expression and quality of life. These changes are connected with the change of state of existence - changes in feelings is interrelated with changes in such values, which makes people think of stable survival. 


\section{Int. Conf. SOCIETY. HEALTH. WELFARE; Congr. of Rehabilitation Doctors of Latvia}

Consumer society brings forward quality of conditions of its life form, which levels value acceptance. The existence normative of consumer society is consumption of services and goods. Young people, the same as other members of society and social groups, are forced independently to form strategies of their life insurance, which are enforced by consumer society.

\section{The role of media and mass culture in value choice}

A youngster meets two essential problems, when he/she forms own value orientation. 1. As a result of compliance with any ready viewpoint offered from outside, he/she is being deprived from the ability to form independent, critical thinking, value system. Especially media constructs the thinking of society. The experience of the last decades shows, that position of a citizen in mass media becomes continuously weaker and weaker. Consumer choices and market research are those, which establish the contents of our communication, but not the concept of what information would be necessary for people (Bardoel, Haenens, 2004). Choosing passive compliance with conventions, reproduction of opinions of authoritative people, a youngster risk to become manipulative - a person, who cannot question the received information. By reproducing someone's opinion and automatically accepting it, a person does not learn to examine information, facts, opinions. Besides, this value system is not able to answer many questions of modern changing world, and again young people come to conclusion, that they are not able to understand and examine the processes in society, from the other side young people do not want to accept anything imposed with force (Rubene, 2008). Gustave Le Bon in his work The Crowd: A Study of the Popular Mind, emphasized that no matter how special is an individual with his/her unique character, lifestyle, intellectual potential or occupation, sooner or later he/she accepts "collective soul".

One of centers of sociological research - Data Serviss, which performed research from 2002 on values of society in the country, declare that "in Latvia the focus is directed towards competition of consumer society" and emphasizes that values of people are choice, which "they make between many competitive alternatives, in such way defining what is important in their lives. Values are a way how people understand each other, placing one for or against the other". Data Serviss in its basic position places value choice as a contrast battle - either "with me" or "against me", which is wrong in its basic ultimatum of research. It is fact, that values are possible to understand in the context of values of other people, helping to form social character of young people and in relationships with other people, such values as - life, family, God, health, etc. are not included in materially measurable category of values, which is examined by Data Serviss in its presentments of value research, evaluating consumer environment in Latvian society (consumer behavior, consumer motivation).

\section{Mass media as the initiator of values}

The communication industry is a significant resource of information, which gives advices the auditorium on entertainment opportunities and on ways of spending spare time. The communication industry turns into the media when it begins to develop stories; these narratives are particularly effectual when and if the reader finds himself interested, when he meets his wishes and moral normatives in these stories. The stories share an opportunity to gain new knowledge of certain culture aspects and new understanding of what and how education it should be, and about its modern contents; it also gives an insight of how far has the society allowed the education to decrease and degenerate. The media offers us an answer to in what world do we live in; and whether we dislike something about the epistle of media, we can also understand where we have gone wrong as a society.

A particular sign of the present age is the orientation of the youth towards the things that change and transfer. The post modern mass thinking turns to "mini values", which, just like the process of consuming, has turned into an instrument of showing the cultural identities of small social groups and parties. The consumer society provides its values and its ways of spending leisure time with the help of the web communication industry. 


\section{SHS Web of Conferences}

The media can be whatever it wants to, it can even be a monument or a street name, which is an fundamental, however, changing, part of the cultural environment. The media is a memorial, which with the intermediation of evaluation, symbols and ritualistic spectacles translates important information, in a certain time and situation, into attitudes, named the monuments "heavyweight media" (Čaupova, 2006) "The (monuments), surely, can occur as present only as an aesthetic decoration, as an element, that supplements the environment; however, more often the main aim of the monuments is to serve to a certain political or/and cultural message" (Zelče, 2010). The books are media. E-education, egovernance, e-magazine, e-commerce, and even e-health is an agent of communication between the actors. For example, in 2003 already $53 \%$ out of all medical authorities were using e-accountancy of the patients.

Also the sociology of education views upon the educational system with a method that is characteristic to to the research of the media; because the content of education translates the information about the socio-cultural processes in space and time. Knowing that the aim of the education system is to subordinate the contents of education to the requirements and needs of the present reality; to create an appropriate material basis for the study of the new information technologies; it is even now becoming to be understandable and acceptable that the global role of the media affects the social subject in a way of strategic identification.

The ability of scholars to critically analyse the mass media and the contents of it is not controlled, because the basic requirements when learning a subject, are not advanced towards the critical thinking and the sorting out of the causes and consequences of the mass media.

When shaping the youth's bases of values, they come to two significant choices - firstly, the fact that when choosing to obey so some already-made opinions given from someone in the periphery (the informative flow of the media, or the reproduction of the mass culture idol ideas and opinions) a passive compliance of conventions is taking place. The juvenile is not trying to come to conclusions through a certain text of the author, in stead, they do it through a visual, post modernly provided fragmented image. The acceptance of images as the model of reality shapes the youth's future's visions.

It is known that in the society there are several levels of communication, whose communication differences are in connection mainly with the amount of participants. There is an objective meaning of the types of media and the speed of the exchange of information, because the type and the form of handing sets the content's interpretation and borders. The content of mass communication and the market studies set the wants of consumers; and not the notions about what information would be necessary for a human. (Bardeol, Haenens, 2004).

The politics of education should be given a special importance in the age of economic crisis when mass thinking and wants is being formed by the web of media.

For example, the presence of social mythology - math and natural sciences will guarantee you all the competences. It clearly shows in a document such as "Latvia's membership in the European Union, aims, priorities and actions from year 2007 to 2013" in chapter "Education and science development", where it is highlighted that natural sciences and math has a priority role in Latvia. This kind of setting works as a direct process reflection of consumer thinking - money attraction to a certain system of administration, only one education role is bureaucratic to one administrative principle, whose long-term education philosophy result is a suppressed creativity and the choice of an individual is determined. The prestige of exact sciences has not justified itself. The education must not only educate the society, but also has to carry a comprehensive content that would hold culture memories and the transfer of it. (The concept is overtaken from the German cultoroligst Jan Asman, who bases his theory on M. Halbswachs collective memory concept.)

N.Luhmann's system theory's questions of the lack of criticality in the society or the "blindness" is linked to the uncritical analysis of stereotypes, prejudices and the never-ending amount of "social mythology". Preference analysis, at the same time, is also the analysis of the borders of the society (Beitnere, 2003). 


\section{Int. Conf. SOCIETY. HEALTH. WELFARE; Congr. of Rehabilitation Doctors of Latvia}

The magazines dedicated to health have created "a new modern cultural industry and they represent a commercialized "will to be well". The contents of media about style, fashion and beauty makes us think of naturality, practical life; but the sensuous commercials about the sexual relationships as a norm of life quality. For example, the content of subject in the general secondary education subject "health learning" translates the content which is highlined in the mass media, just like the topics: the start of sexual relationships, contraception, and the visualization of it is being supported by teen and women magazines (for example"Puff" and "Sīrups").

Health, sports, healthy lifestyle is also one of the main motive elements of the contents of education, that is why in the research project "Value choice in consumer society" it was found that $30 \%$ out of 625 respondents noted health as one of the top five values.

\section{Conclusions}

Social-cultural factors, such as media, has affected value choice of young people, making these people as consumer thinking objects, but requirements of standards, contents and norms of subjects of education are not able to provide connection of value education with value norms of consumer society.

Young people, choosing values of consumer society, base their motivation on provision of higher quality and competitive ability of life.

Economic crisis in the country and massive emigration to Ireland and England made young people think of their personal safety. To obtain good education - good education is considered as the one which provides material safety.

\section{References}

[1] Bardoel, J., de. Haenenn, L. (2004) Media Meet the Citizen. Eureopean Journal Communication $\mathrm{N}, 19$.

[2] Beitnere, D. (2003) Pašreference latviešu kultūras paradigmā (20. gadsimta 20.-40. un 90. gadi līdz mūsdienām). Promocijas darbs. http://www.dzivesstasts.lv/admin/ content_files/Beitnere_prom.pdf

[3] Inglehart, R. (2008) Changing Values among Western Publics from 1970 to 2006. West European Politics, Vol. 31, January-March, p. 130-146.

[4] Inglehart, R. (1999) Globalization and Postmodern Values Welzel. Modernisation, Cultural Change, and Democracy: the Human. Inglehart, R. C. Development Sequence. Cambridge: Cambridge University Press, 2005. Copyright 1999 by The Center for Strategic and International Studies and the Massachusetts Institute of Technology. The Washington Quarterly, p. 215-228.

[5] Koralseva, I., Rugule, R., Sniksere, S. (2009) A portret of Latvian youth today: integration in society and marginalization risks. R̄̄ga: LU akadēmiskais apgāds, p. 150-161 (in Latvian).

[6] Prudky, L. (2010) Then and Now.Czech society after 20 years. Plzen, p. 10-15.

[7] Rubene, Z. (2008) Kritiskās domāšana mūsdienu izglītības filozofijā. Rīga: Zvaigzne ABC.

[8] Salvatore, J., Babones, S. (2010, 2009) Trade globalization, economic development and the importance of education-as-knowledge. Journal of Sociology 2010, p. 46; 45, originally published online Nov 20, 2009.

[9] Trapeniece, I. (2009) A portret of Latvian youth today: integration in society and marginalization risks. Rīga: LU akadēmiskais apgāds, p. 13-21 (in Latvian).

[10] Research: People, and organization of values; Pētījums: Cilvēks. Vērtība. Organizācija. http: //www. data.1v/index . php?id=26 (look at 09.09.2010).

[11] Zelče, V. (2010) Atmiņu tekstūra Otrā pasaules kara pieminekļi Baltijas valstīs. Latvijas sociālā atminga un identitāte manuskripti, 1. laidiens. http://www.nacionalaidentitate.1v/ wp-content/uploads/2010/12/Manuskripti-1.pdf 5 lpp. 